\title{
Factors Affecting Library Anxiety of Graduate School Students in Gadjah Mada University
}

\section{Faktor-Faktor yang Mempengaruhi Kecemasan Perpustakaan pada Mahasiswa Sekolah Pascasarjana Universitas Gadjah Mada}

\section{Eko Noprianto}

Sekolah Pasca Sarjana, Universitas Gadjah Mada

\section{Abstract}

Background of Study: The library has an important role in supporting the process of education and research in a university. Students need a library as a place to study, discuss, work on assignments, or do research. But sometimes students who visit the library feel uncomfortable and confused about the condition they are facing that is usually known as library anxiety.

Purpose: This study aims at identifying library anxiety among Graduate School Students in Gadjah Mada University, and examine several factors considered to affect library anxiety, namely barriers to service by librarians, affective, library comfort, knowledge of the library, mechanical/technological, information retrieval, regulation, resources.

Method: This is a-quantitative deductive research, using a survey approach. The population were Graduate School Students at Gadjah Mada University, with a total sample of 60 students taken by purposive sampling technique. Data were collected using questionnaires. The data were analyzed using smartPLS 3.0 .

Finding: The results showed that $95 \%$ of Graduate School students at Gadjah Mada University experienced library anxiety. There are 8 factors that affecting library anxiety of Graduate School Students in Gadjah Mada University, namely barriers to service by librarians, affective, library comfort, knowledge of the library, mechanic/technology, information retrieval, regulation, resources.

Conclution: The library anxiety experienced by Graduate School students in Gadjah Mada University is $100 \%$ influenced by those 8 factors tested in this study.

Keywords: library anxiety, library anxiety scale, graduate students
Paper Type:

Research Paper

Submitted 26 May 2019 Accepted 22 December 2019

* Correspondence: Eko Noprianto

E-mail: ekonoprianto92@gmail.com 


\begin{abstract}
Abstrak
Latar Belakang Masalah: Perpustakaan memiliki peran penting dalam mendukung proses pendidikan dan penelitian di sebuah perguruan tinggi. Mahasiswa membutuhkan perpustakaan sebagai tempat untuk belajar, berdiskusi, mengerjakan tugas kuliah, maupun untuk penelitian. Namun adakalanya mahasiswa yang berkunjung ke perpustakaan merasa tidak nyaman dan bingung dengan situasi yang dihadapinya yang dikenal dengan istilah kecemasan perpustakaan.

Tujuan: Penelitian ini bertujuan untuk mengidentifikasi ada tidaknya kecemasan perpustakaan pada mahasiswa Sekolah Pascasarjana UGM, serta menguji beberapa faktor yang dianggap mempengaruhi kecemasan perpustakaan tersebut, yaitu hambatan pelayanan oleh pustakawan, afektif, kenyamanan perpustakaan, pengetahuan tentang perpustakaan, mekanis/teknologi, temu kembali informasi, regulasi, sumber informasi.

Metode: Jenis penelitian ini adalah deduktif kuantitatif, dengan menggunakan pendekatan survei. Populasi penelitian adalah mahasiswa Sekolah Pascasarjana UGM, dengan jumlah sampel sebanyak 60 mahasiswa yang diambil dengan teknik purposive sampling. Pengumpulan data dilakukan dengan menyebarkan kuesioner. Data penelitian dianalisis menggunakan smartPLS 3.0.

Temuan: Hasil penelitian menunjukkan bahwa 95\% mahasiswa Sekolah Pascasarjana UGM mengalami kecemasan perpustakaan. Terdapat 8 faktor yang mempengaruhi kecemasan perpustakaan pada mahasiswa Sekolah Pascasarjana UGM, yaitu hambatan pelayanan oleh pustakawan, afektif, kenyamanan perpustakaan, pengetahuan tentang perpustakaan, mekanis/teknologi, temu kembali informasi, regulasi, sumber informasi.
\end{abstract}

Simpulan: Kecemasan perpustakaan yang dialami mahasiswa Sekolah Pascasarjana UGM 100\% dipengaruhi oleh 8 faktor yang diujikan dalam penelitian ini.

Kata Kunci: kecemasan perpustakaan, skala kecemasan perpustakaan, mahasiswa pascasarjana 


\section{Pendahuluan}

Mahasiswa di sebuah perguruan tinggi tidak akan terlepas dari kegiatan berinteraksi dengan perpustakaan, tentunya dengan alasan dan tujuan yang berbeda-beda, misalnya untuk mencari referensi, mengerjakan tugas kuliah, berdiskusi, ataupun hanya untuk memanfaatkan fasilitas internet yang disediakan perpustakaan. Hal ini sejalan dengan pernyataan Ahmed dan Aziz (2017) bahwa mahasiswa membutuhkan perpustakaan untuk mengakses informasi dalam mendukung pembelajaran dan penelitian mereka. Namun adakalanya mahasiswa yang berkunjung ke perpustakaan mengalami kecemasan dengan situasi yang dihadapinya. Kecemasan tersebut dapat disebabkan oleh ukuran gedung perpustakaan, mahasiswa kurang mengetahui tentang penempatan atau tata letak perpustakaan, bagaimana melakukan sesuatu di perpustakaan, dan apa yang harus dilakukan (Mellon, 1986).

Kead aan tersebut dikenal dengan istilah Kecemasan Perpustakaan (library anxiety). Kecemasan perpustakaan merupakan perasaan tidak nyaman atau tidak menentu, yang dialami oleh mahasiswa sewaktu menggunakan perpustakaan atau saat memikirkan bagaimana menggunakan perpustakaan (Jiao \& Onwuegbuzie, 1997). Menurut Erfanmanesh (2011) Kecemasan perpustakaan terdiri dari gejala-gejala emosional negatif seperti ketakutan, khawatir, ketidakpastian, merasakan kurangnya kemampuan dan efisiensi dalam menggunakan perpustakaan, rasa kesepian, ketakutan, dan lain-lain. Hal ini juga berdampak pada efektivitas pemanfaatan koleksi maupun fasilitas perpustakaan oleh mahasiswa. Oleh sebab itu, pihak perpustakaan harus memberikan perhatian yang serius dalam mengembangkan strategi atau kebijakan dalam mengatasi permasalahan tersebut (McPherson, 2015), mengingat perpustakaan adalah sebagai tempat utama dalam mengembangkan pembelajaran mahasiswa. Menurut Jan, Anwar, dan Warraich (2016) mahasiswa dapat meningkatkan keberhasilan akademik mereka dalam hal nilai Indeks Prestasi Kumulatif (IPK) dengan memanfaatkan perpustakaan dan sumber dayanya secara efektif.

Pada tahun 1992, Sharon L. Bostick telah mengembangkan sebuah skala untuk pengukuran tingkat kecemasan perpustakaan secara kuantitatif, yang disebut dengan Library Anxiety Scale (LAS). LAS terd iri dari 5 faktor dimensi, diantaranya: hambatan dengan staf (pustakawan), hambatan afektif, hambatan kenyamanan di perpustakaan, pengetahuan tentang perpustakaan, dan hambatan mekanis. Skala ini telah digunakan secara luas hampir di seluruh dunia. Namun demikian, ada pendapat mengatakan bahwa kecemasan perpustakaan adalah fenomena yang unik dan bersifat independen(Jiao dan Onwuegbuzie, 1999), sehingga perlu dilakukan penelitian lebih lanjut untuk memahami fenomena kecemasan perpustakaan di tempat yang berbeda. Świgoń (2011) juga menjelaskan bahwa perbedaan budaya mengharuskan peneliti melakukan modifikasi instrumen penelitian untuk mengukur tingkat kecemasan perpustakaan. Selain itu, di era teknologi informasi dan komunikasi (TIK) banyak perpustakaan yang memberikan layanan informasi elektronik, sehingga ini juga mendorong adanya pengembangan skala untuk mengukur tingkat kecemasan yang dialami mahasiswa dalam memanfaatkan sumber informasi elektronik yang disediakan perpustakaan. Menarik untuk mengkaji dan menggali faktor-faktor yang berpotensi menyebabkan kecemasan perpustakaan pada mahasiswa yang ada di Indonesia. Penelitian ini akan difokuskan pada mahasiswa Sekolah Pascasarjana Universitas Gadjah Mada (UGM). Sebelumnya Kurnia (2017) telah melakukan penelitian dengan topik yang sama pada mahasiswa Sekolah Pascasarjana UGM menggunakan LAS. Hasil penelitiannya membuktikan bahwa secara keseluruhan mahasiswa Sekolah Pascasarjana UGM mengalami kecemasan perpustakaan yaitu pada tingkat kecemasan rendah.

Berdasarkan penelitian tersebut, peneliti bermaksud untuk melakukan penelitian dengan topik yang sama. Penelitian ini menggunakan 3 skala kecemasan perpustakaan yaitu LAS (Bostick, 1992), Polish Translated Library Anxiety Scale (P-LAS) (Swigon, 2011), dan Chinese Translated Library Anxiety Scale (C-LAS) (Song, Zhang, \& Clarke, 2014), dengan cara menggabungkan tiga skala tersebut. Hal ini bertujuan untuk menggali faktor-faktor lain yang berpengaruh terhadap kecemasan perpustakaan pada mahasiswa Sekolah Pascasarjana UGM. Mengingat pada saat ini, Perpustakaan UGM juga telah memberikan layanan informasi elektronik, sehingga skala pengukuran perlu disesuaikan atau dikembangkan untuk mengukur tingkat kecemasan perpustakaan. Penelitian ini

To cite this document:

Noprianto, E. (2019). Factors Affecting Library Anxiety of Graduate School Students in Gadjah Mada University. Record and

Library Journal. 5 (2), 207-217

Open access under Creative Commons Attribution-Non Commercial-Share A like 4.0 International Licence 
diharapkan bisa menghasilkan model baru yang lebih sesuai untuk mengukur tingkat kecemasan perpustakaan dan bisa digunakan atau diuji kembali di tempat yang berbeda khususnya di Indonesia.

Berdasarkan penjelasan di atas, maka diajukan pertanyaan penelitian sebagai berikut: (1) Apakah ada kecemasan perpustakaan pada mahasiswa Sekolah Pascasarjana UGM? (2) Faktor-faktor apa saja yang mempengaruhi kecemasan perpustakaan pada mahasiswa Sekolah Pascasarjana UGM? Penelitian ini bertujuan untuk mengidentifikasi kecemasan perpustakaan pada mahasiswa Sekolah Pascasarjana UGM dan mencari faktor-faktor yang mempengaruhi kecemasan perpustakaan pada mahasiswa Sekolah Pascasarjana UGM. Penelitian ini diharapkan dapat memberikan sumbangsih pemikiran terhadap perkembangan ilmu perpustakaan dan informasi, serta dapat dijadikan sebagai rujukan untuk penelitian selanjutnya dalam topik penelitian yang sama. Selain itu, penelitian ini diharapkan dapat memberikan informasi tentang faktor-faktor yang menyebabkan kecemasan perpustakaan, sehingga dapat membantu pihak Perpustakaan Universitas Gadjah Mada dalam membuat kebijakan untuk mengatasi kecemasan perpustakaan tersebut.

\section{Tinjauan Pustaka}

\section{Skala Pengukuran Kecemasan Perpustakaan}

Mellon (1986) melakukan penelitian secara kualitatif, dan menghasilkan 4 faktor yang menyebabkan kecemasan perpustakaan, diantaranya: ukuran gedung perpustakaan, kurang mengetahui tentang penempatan atau tata letak perpustakaan, bagaimana melakukan sesuatu di perpustakaan, dan apa yang harus dilakukan. Mahasiswa yang mengalami kecemasan diperpustakaan akan merasa kurang percaya diri, yang diwujudkan dalam 3 hal berikut: Pertama, mahasiswa merasa dirinya kurang berkompeten atau tidak memiliki keterampilan penggunaan perpustakaan yang memadai dibanding mahasiswa lainnya. Kedua, mahasiswa menganggap ketidakmampuan tersebut adalah hal yang memalukan dan harus disembunyikan. Ketiga, perasaan malu tersebut menyebabkan mahasiswa enggan bertanya kepada pustakawan (Mellon, 1986). Dari penelitian tersebut, Mellon menetapkan teori tentang kecemasan perpustakaan. Dengan alasan bahwa ketika mahasiswa mencari informasi di perpustakaan untuk pertama kalinya, kebanyakan dari mereka mengalami kecemasan.

Pada tahun 1992, Bostick mengembangkan dan memvalidasi skala pengukuran kecemasan perpustakaan secara kuantitatif. Hasil penelitian Bostick (1992) mengidentifikasi lima faktor yang mempengaruhi kecemasan perpustakaan diantaranya: hambatan dengan pustakawan (barriers with staff); hambatan afektif (affective barriers); hambatan dengan kenyamanan di perpustakan (library comfort barriers); hambatan pengetahuan tentang perpustakaan (knowledge of the library); dan hambatan mekanik (mechanical barriers). Jiao dan Onwuegbuzie (1997) memberikan definisi terhad ap 5 faktor dimensi tersebut sebagai berikut: (1) Hambatan dengan pustakawan merupakan persepsi mahasiswa terhadap pustakawan yang terlihat menakutkan dan tidak bisa didekati. Selain itu, pustakawan terlihat sangat sibuk dengan pekerjaannya sendiri. Mahasiswa yang memiliki persepsi seperti ini cenderung mengalami kecemasan perpustakaan. (2) Hambatan afektif merupakan perasaan tidak mampu dalam menggunakan perpustakaan, karena kurang memiliki keterampilan penggunaan perpustakaan. (3) Hambatan kenyamanan perpustakaan mengacu pada perasaan aman, merasa diterima, dan lingkungan perpustakaan yang tidak membahayakan. (4) Pengetahuan tentang perpustakaan mengacu pada perasaan seberapa akrab mahasiswa dengan perpustakaan. Konsep ini merujuk pada pengetahuan mahasiswa terhadap penggunaan fasilitas maupun koleksi perpustakaan. (5) Hambatan mekanis berkaitan dengan perasaan yang muncul sebagai akibat ketergantungan mahasiswa pada peralatan mekanis, seperti printer, komputer, mesin fotokopi, dan lain-lain.

Sejak penelitian Bostick (1992), banyak peneliti mulai tertarik untuk melakukan penelitian tentang kecemasan perpustakaan menggunakan LAS. Hal ini didorong oleh pernyataan Bostick (1992) bahwa LAS perlu diuji di lingkungan pendidikan yang berbeda. Selain itu, Jiao dan Onwuegbuzie (1999) mengatakan bahwa kecemasan perpustakaan adalah fenomena yang unik dan bersifat independen, sehingga penting adanya penelitian untuk menggali faktor-faktor yang berpotensi menyebabkan kecemasan perpustakaan. Transformasi layanan perpustakaan ke arah layanan online juga

To cite this document:

Noprianto, E. (2019). Factors Affecting Library Anxiety of Graduate School Students in Gadjah Mada University. Record and

Library Journal. 5 (2), 207-217

Open access under Creative Commons Attribution-Non Commercial-Share A like 4.0 International Licence

(CC-BY-SA) 
telah dianggap sebagai faktor yang menyebabkan kecemasan perpustakaan. Pengembangan skala pengukuran kecemasan perpustakaan pernah dilakukan oleh Swigon (2011) di Polandia dan Song et al. (2014) di Cina.

Penelitian Swigon (2011) di Polandia, menghasilkan skala baru untuk pengukuran kecemasan perpustakaan pada mahasiswa Polandia. Swigon mengatakan bahwa skala kecemasan perpustakaan yang dikembangkan di Amerika Serikat tidak sesuai untuk diterapkan di Polandia. Permasalahan terbesar pada perpustakaan universitas diPolandia yaitu kekurangan sumber informasi elektronik (buku maupun jurnal). Penelitian Swigon (2011) menghasilkan 6 faktor dimensi yang menyebabkan kecemasan perpustakaan, diantaranya: hambatan dengan pustakawan, hambatan afektif, hambatan kenyamanan perpustakaan, pengetahuan tentang perpustakaan, hambatan teknologi, dan hambatan sumber informasi.

Terdapat perbedaan antara LAS dan P-LAS yaitu hambatan mekanis dan hambatan teknologi. Bostick menggunakan istilah hambatan mekanis, yang mana dalam hambatan ini merujuk pada penggunaan teknologi yang bersifat mekanis (misalnya: mesin fotokopi, printer). Sedangkan P-LAS menggunakan istilah hambatan teknologi, yang mana hambatan ini merujuk pada penggunaan teknologi yang bersifat mekanis dan TIK (misalnya: elektronik database, katalog online, internet). Kemudian dalam P-LAS terdapat satu faktor dimensi baru yang belum ditemukan oleh penelitian Bostick (1992) yaitu hambatan sumber informasi. Hambatan sumber informasi ini merujuk pada kekurangan sumber informasi di perpustakaan, baik dalam bentuk cetak maupun elektronik yang disediakan perpustakaan, serta kemudahan akses terhad ap koleksi tersebut. Kemudahan akses berkaitan dengan jaringan internet di perpustakaan. Jaringan internet yang buruk akan menghambat mahasiswa untuk mendapatkan sumber informasi elektronik dari database yang di langgan perpustakaan.

Selanjutnya, Song et al. (2014) melakukan penelitian tentang kecemasan perpustakaan dikalangan mahasiswa Cina. Penelitian tersebut berhasil memodifikasi LAS menjadi 7 faktor dimensi, diantaranya: Hambatan sumber informasi, hambatan temu kembali, hambatan regulasi, hambatan dengan pustakawan, hambatan perasaan, hambatan kenyamanan perpustakaan, dan pengetahuan tentang perpustakaan.

Perbedaan antara C-LAS dengan 2 skala lainnya (LAS \& P-LAS) yaitu pada hambatan temu kembali (retrieval) dan hambatan regulasi. Hambatan temu kembali berkaitan dengan kecemasan yang dialami mahasiswa saat mencari informasi di perpustakaan. Konsep ini merujuk pada sistem temu kembali informasi dan tampilan antarmuka (interface). Selain itu, kemampuan dalam temu kembali informasi juga perlu diukur sebagai komponen yang berkontribusi dalam hambatan temu kembali. Selanjutnya hambatan regulasi berkaitan dengan kecemasan yang dialami mahasiswa terhadap peraturan di perpustakaan, misalnya batas waktu peminjaman, denda keterlambatan pengembalian, dan jam buka layanan perpustakaan.

\section{Pengembangan Skala Pengukuran Kecemasan Perpustakaan}

Pengembangan skala kecemasan Perpustakaan dalam penelitian ini mengadopsi 3 skala pengukuran yaitu LAS (1992), Polish Translated Library Anxiety Scale (P-LAS) yang dikembangkan oleh Swigon (2011), dan Chinese Translated Library Anxiety Scale (C-LAS) yang dikembangkan oleh Song et al. (2014). Tiga skala kecemasan perpustakaan tersebut, memiliki beberapa faktordimensi yang sama, maka dalam penelitian ini faktor-faktor tersebut dikerucutkan menjadi 8, diantaranya: Hambatan dengan pustakawan, Hambatan afektif, Hambatan kenyamanan perpustakaan, Pengetahuan tentang perpustakaan, Hambatan mekanis/teknologi, Hambatan temu kembali, Hambatan regulasi, Hambatan sumber informasi. Berdasarkan hal tersebut, maka kerangka konseptual penelitian dapat digambarkan sebagai berikut:

To cite this document:

Noprianto, E. (2019). Factors Affecting Library Anxiety of Graduate School Students in Gadjah Mada University. Record and

Library Journal. 5 (2), 207-217

Open access under Creative Commons Attribution-Non Commercial-Share A like 4.0 International Licence 


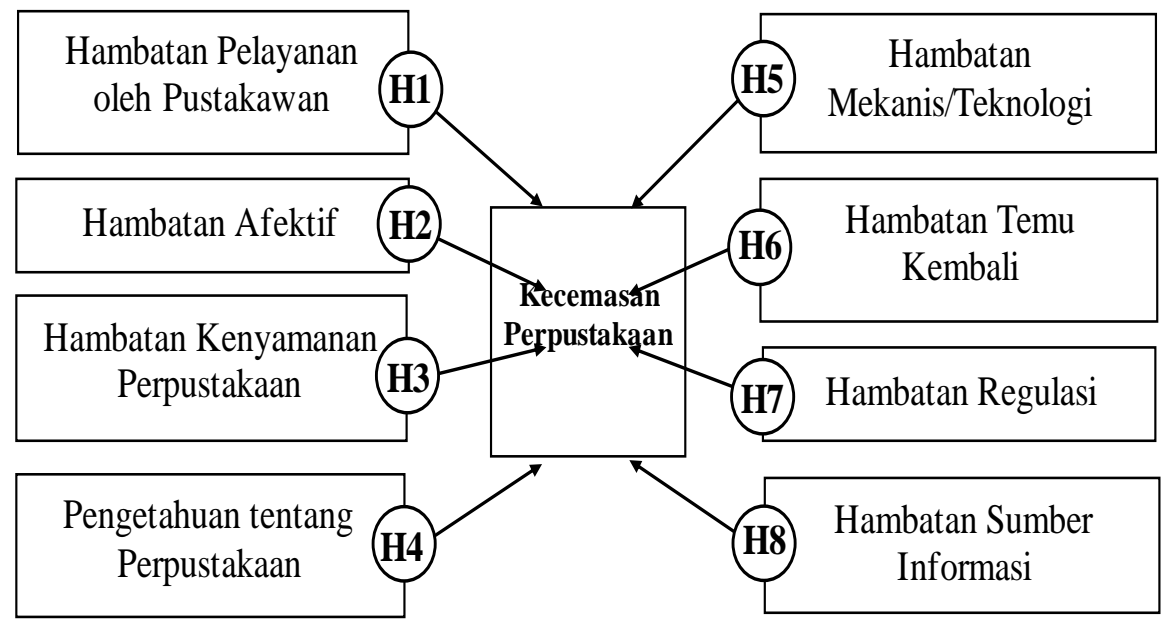

\section{Hipotesis}

Gambar 1. Kerangka Konseptual Penelitian

Menurut Bostick (1992) yang melakukan penelitian di Amerika Serikat, kecemasan perpustakaan dibentuk oleh lima faktor dimensi yaitu hambatan pelayanan oleh pustakawan, hambatan afektif, hambatan kenyamanan perpustakaan, pengetahuan tentang perpustakaan, dan hambatan mekanis. Berbeda dengan hasil penelitian Swigon (2011) di Polandia, dia menemukan dua faktor baru yang dapat berpengaruh terhadap kecemasan perpustakaan, yaitu hambatan teknologi dan hambatan sumber informasi. Dua penelitian ini dilakukan pada masa yang jauh berbeda. Swigon (2011) melakukan penelitian pada era teknologi informasi dan komunikasi yang lebih canggih, sehingga tren yang berkembang di perpustakaan adalah sumber informasi elektronik. Dengan demikian, bisa diterima ketika Swigon menyatakan adanya hambatan teknologi dan hambatan sumber informasi yang dapat mempengaruhi kecemasan perpustakaan. Selanjutnya, penelitian terbaru dilakukan oleh Song et al. (2014) di Cina. Penelitian tersebut menemukan beberapa hambatan lain yang berpengaruh terhadap kecemasan perpustakaan, yaitu terkait dengan sistem temu kembali informasi dan regulasi perpustakaan. Berdasarkan penjelasan tersebut, maka diajukan hipotesis sebagai berikut:

H1: Hambatan pelayanan oleh pustakawan berpengaruh terhadap kecemasan perpustakaan pada mahasiswa Sekolah Pascasarjana UGM.

H2: Hambatan afektif berpengaruh terhadap kecemasan perpustakaan pada mahasiswa Sekolah Pascasarjana UGM.

H3: Hambatan kenyamanan perpustakaan berpengaruh terhadap kecemasan perpustakaan pada mahasiswa Sekolah Pascasarjana UGM.

H4: Pengetahuan tentang perpustakaan berpengaruh terhadap kecemasan perpustakaan pada mahasiswa Sekolah Pascasarjana UGM.

H5: Hambatan mekanis/teknologi berpengaruh terhadap kecemasan perpustakaan pada mahasiswa Sekolah Pascasarjana UGM.

H6: Hambatan temu kembali berpengaruh terhadap kecemasan perpustakaan pada mahasiswa Sekolah Pascasarjana UGM.

H7: Hambatan regulasi berpengaruh terhadap kecemasan perpustakaan pada mahasiswa Sekolah Pascasarjana UGM.

H8: Hambatan sumber informasi berpengaruh terhadap kecemasan perpustakaan pada mahasiswa Sekolah Pascasarjana UGM.

\section{Metode Penelitian}

Penelitian ini menggunakan pendekatan kuantitatif, dimana tujuan penelitian kuantitatif adalah mendapatkan penjelasan tentang besarnya kebermaknaan dalam model yang dihipotesiskan sebagai jawaban atas masalah yang telah dirumuskan (Indrawan \& Yuniawati, 2016). Penelitian ini

To cite this document:

Noprianto, E. (2019). Factors Affecting Library Anxiety of Graduate School Students in Gadjah Mada University. Record and

Library Journal. 5 (2), 207-217

Open access under Creative Commons Attribution-Non Commercial-Share A like 4.0 International Licence 
menggunakan metode survei, yaitu suatu metode penelitian untuk mengumpulkan informasi dengan cara terorganisir dan mengikuti metode ilmiah tentang karakteristik dari semua atau sebagian populasi (Asra, Irawan, \& Purwoto, 2015). Penelitian dilakukan di Perpustakaan Universitas Gadjah Mada, dengan populasi penelitian adalah mahasiswa aktif Sekolah Pascasarjana UGM yang mengalami kecemasan perpustakaan. Dengan demikian jumlah populasi dalam penelitian ini tidak ketahui, sehingga untuk menentukan jumlah sampel menggunakan rumus Isac Michel (Siregar, 2014), sebagai berikut:

$$
\begin{aligned}
& \text { Rumus: } \quad n=\frac{\left(z_{\alpha}\right)^{2} p \cdot q}{e^{2}} \\
& \text { Keterangan: } \quad \mathrm{n}=\text { sampel, } \\
& \mathrm{p}=\text { proporsi populasi, } \\
& \text { (estimasi proporsi } 0,1 \text { hingga } 0,5 \text { ) } \\
& \mathrm{q}=1-\mathrm{p},
\end{aligned}
$$

Penelitian Kurnia (2017) memberikan kesimpulan bahwa secara umum kecemasan perpustakaan pada mahasiswa Sekolah Pascasarjana UGM berada pada tingkat kecemasan rendah. Mempertimbangkan hasil penelitian tersebut, maka ditetapkan proporsi mahasiswa yang mengalami kecemasan perpustakaan 0,3 dengan tingkat kepercayaan 90\% dan tingkat kesalahan 10\%, sehingga dapat dilakukan penghitungan jumlah sampel sebagai berikut:

$$
\begin{array}{ll} 
& =1,64 \text { (berdasarkan tabel distribusi normal) } \\
\mathrm{p} & =0,3 \\
\mathrm{q} & =1-0,3=0,7 \\
\mathrm{e} & =0,1 \\
\text { maka: } & \text { dibulatkan menjadi } 60
\end{array}
$$

Berdasarkan penghitungan di atas, didapatkan jumlah sampel sebesar 56,48, namun untuk mengantisipasi kesalahan (sampling error), jumlah sampel dibulatkan menjadi 60 mahasiswa. Adapun teknik pengambilan sampel yang digunakan dalam penelitian ini adalah purposive sampling, yaitu teknik penetapan responden yang akan dijadikan sebagai sampel berdasarkan pada kriteria-kriteria tertentu (Siregar, 2014).

Pengumpulan Data penelitian menggunakan kuisioner dan studi pustaka. Data penelitian ini dianalisis menggunakan structural equation model (SEM) berbasis component atau variance dengan menggunakan metode partial least square (PLS). Analisis data dengan SEM-PLS terd iri dari dua tahap yaitu evaluasi model pengukuran dan evaluasi model struktural. Uji hipotesis dalam penelitian ini dilakukan dengan metode PLS menggunakan aplikasi SmartPLS. Pengambilan keputusan terhadap pengujian hipotesis dilakukan dengan melihat perbandingan antara nilai tstatistik dengan nilai ttabel. Jika nilai tstatistik lebih besar dari nilai ttabel maka terdapat pengaruh dan signifikansi. Sebaliknya, jika nilai tstatistik lebih kecil dari nilai ttabel maka tidak terdapat pengaruh dan signifikansi.

\section{Hasil}

\section{Kecemasan Perpustakaan pada Mahasiswa Sekolah Pascasarjana UGM}

Sebanyak 60 responden telah berpartisipasi mengisi kuisioner penelitian, yang terdiri dari $57 \%$ (34 mahasiswa) perempuan dan 43\% (26 mahasiswa) laki-laki. Pengumpulan data penelitian dimulai sejak pertengahan Februari hingga akhir Maret 2019. Hasil penelitian menunjukkan bahwa 95\% atau sebanyak 57 mahasiswa Sekolah Pascasarjana UGM mengalami kecemasan perpustakaan, sedangkan 5\% atau sebanyak 3 mahasiswa lainnya tidak mengalami kecemasan perpustakaan. Dengan demikian dapat dinyatakan bahwa ada kecemasan perpustakaan pada mahasiswa Sekolah Pascasarjana UGM.

\section{Evaluasi Model PLS-SEM}

Selanjutnya data penelitian dianalisis menggunakan program SmartPLS 3, untuk menetapkan faktor-faktor yang mempengaruhi kecemasan perpustakaan pada mahasiswa Sekolah Pascasarjana

To cite this document:

Noprianto, E. (2019). Factors Affecting Library Anxiety of Graduate School Students in Gadjah Mada University. Record and

Library Journal. 5 (2), 207-217

Open access under Creative Commons Attribution-Non Commercial-Share A like 4.0 International Licence 
UGM. Data yang dianalisis berjumlah 57 sampel, karena 3 sampel lainnya tidak mengalami kecemasan perpustakaan. Analisis data penelitian dengan pendekatan PLS-SEM terdiri dari dua tahap yaitu evaluasi terhadap model pengukuran (atau disebut juga outer model) dan model struktural (atau disebut juga inner model).

\section{Evaluasi Model Pengukuran}

Evaluasi terhadap model pengukuran adalah untuk memastikan bahwa instrumen penelitian layak digunakan sebagai alat ukur. Evaluasi model pengukuran terdiri dari uji validitas dan reliabilitas . Instrumen dikatakan valid jika memiliki nilai factor loading di atas 0,5 dan instrumen dikatan reliabel jika memiliki nilai composite reliability dan cronbach's alpha di atas 0.70 (Ghozali, 2014). Hasil uji validitas dan reliabilitas menggunakan program SmartPLS 3 ditunjukkan pada tabel dibawah:

Tabel 3. Hasil Uji Validitas

\begin{tabular}{|c|c|c|c|c|c|c|c|c|c|}
\hline & $\mathrm{X} 1$ & $\mathrm{X} 2$ & X3 & $\mathrm{X} 4$ & $\times 5$ & X6 & X7 & $\mathrm{X} 8$ & $Y$ \\
\hline $\mathrm{X} 1.1$ & 0.696 & 0.441 & 0.445 & 0.125 & 0.063 & 0.07 & 0.026 & 0.103 & 0.336 \\
\hline $\mathrm{X} 1.2$ & 0.821 & 0.526 & 0.518 & -0.073 & 0.179 & 0.24 & 0.063 & 0.208 & 0.455 \\
\hline X1.3 & 0.87 & 0.636 & 0.612 & 0.298 & 0.384 & 0.313 & 0.122 & 0.235 & 0.591 \\
\hline X1.5 & 0.743 & 0.443 & 0.52 & 0.097 & 0.232 & 0.155 & -0.048 & 0.142 & 0.399 \\
\hline X1.7 & 0.86 & 0.505 & 0.716 & -0.017 & 0.272 & 0.297 & 0.069 & 0.136 & 0.5 \\
\hline $\mathrm{X} 2.2$ & 0.505 & 0.706 & 0.373 & 0.321 & 0.313 & 0.341 & 0.235 & 0.186 & 0.513 \\
\hline $\mathrm{X} 2.3$ & 0.46 & 0.669 & 0.383 & 0.195 & 0.366 & 0.437 & 0.2 & 0.317 & 0.542 \\
\hline $\mathrm{X} 2.5$ & 0.671 & 0.857 & 0.719 & 0.295 & 0.551 & 0.487 & 0.415 & 0.447 & 0.773 \\
\hline X2.6 & 0.526 & 0.812 & 0.583 & 0.13 & 0.502 & 0.596 & 0.274 & 0.332 & 0.678 \\
\hline $\mathrm{X} 2.7$ & 0.317 & 0.708 & 0.393 & 0.374 & 0.492 & 0.395 & 0.425 & 0.33 & 0.588 \\
\hline $\mathrm{X} 2.8$ & 0.31 & 0.624 & 0.333 & 0.147 & 0.442 & 0.386 & 0.269 & 0.436 & 0.537 \\
\hline X3.4 & 0.479 & 0.513 & 0.733 & 0.37 & 0.571 & 0.502 & 0.31 & 0.467 & 0.666 \\
\hline X3.5 & 0.559 & 0.613 & 0.801 & 0.011 & 0.405 & 0.395 & 0.268 & 0.31 & 0.598 \\
\hline X3.6 & 0.507 & 0.393 & 0.747 & -0.039 & 0.285 & 0.202 & 0.117 & 0.273 & 0.441 \\
\hline X3.7 & 0.634 & 0.41 & 0.746 & 0.06 & 0.208 & 0.262 & 0.013 & 0.139 & 0.426 \\
\hline X4.1 & 0.028 & 0.057 & -0.09 & 0.652 & 0.05 & -0.072 & 92 & 0.056 & 0.093 \\
\hline X4.3 & 0.028 & 0.052 & -0.075 & 0.651 & 0.105 & -0.094 & 0.199 & -0.006 & 0.074 \\
\hline X4.4 & 0.142 & 0.366 & 0.224 & 0.911 & 0.611 & 0.535 & 0.371 & 0.439 & 0.558 \\
\hline X4.5 & 0.021 & 0.165 & 0.053 & 0.645 & 0.164 & 0.002 & 0.288 & 0.269 & 0.218 \\
\hline X5.1 & 0.329 & 0.564 & 0.473 & 0.245 & 0.769 & 0.56 & 0.412 & 0.603 & 0.7 \\
\hline X5.2 & 0.179 & 0.448 & 0.29 & 0.476 & 0.832 & 0.526 & 0.375 & 0.559 & 0.629 \\
\hline X5.4 & 0.148 & 0.389 & 0.441 & 0.416 & 0.798 & 0.598 & 0.343 & 0.514 & 0.621 \\
\hline X5.5 & 0.275 & 0.512 & 0.415 & 0.482 & 0.746 & 0.661 & 0.594 & 0.573 & 0.718 \\
\hline X6.1 & 0.251 & 0.604 & 0.317 & 0.267 & 0.629 & 0.86 & 0.5 & 0.549 & 0.708 \\
\hline X6.2 & 0.227 & 0.448 & 0.447 & 0.382 & 0.702 & 0.861 & 0.474 & 0.708 & 0.739 \\
\hline X6.3 & 0.199 & 0.393 & 0.387 & 0.182 & 0.532 & 0.712 & 0.226 & 0.479 & 0.558 \\
\hline X6.4 & 0.259 & 0.537 & 0.423 & 0.383 & 0.587 & 0.84 & 0.404 & 0.532 & 0.689 \\
\hline X7.1 & -0.154 & 0.085 & 0.072 & 0.362 & 0.347 & 0.204 & 0.644 & 0.522 & 0.328 \\
\hline X7.2 & 0.07 & 0.393 & 0.206 & 0.267 & 0.443 & 0.48 & 0.766 & 0.627 & 0.558 \\
\hline X7.3 & 0.175 & 0.413 & 0.31 & 0.353 & 0.489 & 0.388 & 0.845 & 0.623 & 0.6 \\
\hline X7.4 & 0.013 & 0.282 & 0.14 & 0.285 & 0.374 & 0.379 & 0.74 & 0.466 & 0.444 \\
\hline X8.3 & 0.094 & 0.367 & 0.33 & 0.469 & 0.676 & 0.631 & 0.62 & 0.802 & 0.677 \\
\hline X8.4 & 0.266 & 0.434 & 0.417 & 0.201 & 0.435 & 0.535 & 0.464 & 0.725 & 0.616 \\
\hline
\end{tabular}

To cite this document:

Noprianto, E. (2019). Factors Affecting Library Anxiety of Graduate School Students in Gadjah Mada University. Record and Library Journal. 5 (2), 207-217

Open access under Creative Commons Attribution-Non Commercial-Share A like 4.0 International Licence 


\begin{tabular}{rrrrrrrrrr} 
X8.5 & 0.165 & 0.266 & 0.233 & 0.439 & 0.539 & 0.47 & 0.554 & $\mathbf{0 . 7 9 8}$ & 0.585 \\
X8.6 & 0.179 & 0.515 & 0.299 & 0.29 & 0.636 & 0.627 & 0.702 & $\mathbf{0 . 8 2 8}$ & 0.718 \\
X8.8 & 0.142 & 0.25 & 0.381 & 0.207 & 0.538 & 0.466 & 0.6 & $\mathbf{0 . 8 0 5}$ & 0.589 \\
\hline
\end{tabular}

Sumber: Data diolah April 2019

Tabel 4. Hasil Uji Reliabilitas

\begin{tabular}{lcc}
\hline \multicolumn{1}{c}{ Variabel } & $\begin{array}{c}\text { Composite } \\
\text { Reliability }\end{array}$ & $\begin{array}{c}\text { Cronbach's } \\
\text { Alpha }\end{array}$ \\
\hline Hambatan pelayanan oleh pustakawan (X1) & 0,899 & 0,860 \\
Hambatan afektif (X2) & 0,874 & 0,826 \\
Hambatan kenyamanan perpustakaan (X3) & 0,843 & 0,757 \\
Pengetahuan tentang perpustakaan (X4) & 0,811 & 0,803 \\
Hambatan mekanis teknologi (X5) & 0,867 & 0,795 \\
Hambatan Temu Kembali (X6) & 0,891 & 0,837 \\
Hambatan Regulasi (X7) & 0,838 & 0,745 \\
Hambatan sumber informasi (X8) & 0,894 & 0,851 \\
Kecemasan Perpustakaan (Y) & 0,939 & 0,932 \\
\hline
\end{tabular}

Sumber: Data diolah April 2019

\section{Evaluasi Model Struktural}

Evaluasi terhadap model struktural dilakukan untuk melihat hubungan dan nilai signifikansi antar variabel laten. Evaluasi model struktural adalah dengan melihat nilai koefisien jalur dan nilai $R$-square untuk variabel laten endogen. Pada tabel 5 dibawah, dapat dilihat nilai koefisien jalur dari variabel laten eksogen ke variabel laten endogen. Untuk mengetahui tingkat signifikansi dari nilai koefisien jalur dilihat dari nilai $\boldsymbol{t}_{\text {statistik}}$, yang dihasilkan melalui proses bootstrapping pada program SmartPLS 3.

Tabel 5. Hasil Uji Signifikansi

\begin{tabular}{ccccc}
\hline Hipotesis & Jalur & $\begin{array}{c}\text { Koefisien Jalur } \\
(\mathrm{O})\end{array}$ & $\begin{array}{c}\text { Standar Deviasi } \\
(\text { STDEV })\end{array}$ & $\begin{array}{c}\text { T Statistik } \\
(|\mathrm{O} / \mathrm{STDEV}|)\end{array}$ \\
\hline $\mathrm{H} 1$ & $\mathrm{X} 1 \rightarrow \mathrm{Y}$ & 0.160 & 0.050 & 3.192 \\
$\mathrm{H} 2$ & $\mathrm{X} 2 \rightarrow \mathrm{Y}$ & 0.234 & 0.029 & 7.992 \\
$\mathrm{H} 3$ & $\mathrm{X} 3 \rightarrow \mathrm{Y}$ & 0.140 & 0.027 & 5.131 \\
$\mathrm{H} 4$ & $\mathrm{X} 4 \rightarrow \mathrm{Y}$ & 0.066 & 0.027 & 2.471 \\
$\mathrm{H} 5$ & $\mathrm{X} 5 \rightarrow \mathrm{Y}$ & 0.182 & 0.022 & 8.283 \\
$\mathrm{H} 6$ & $\mathrm{X} 6 \rightarrow \mathrm{Y}$ & 0.193 & 0.023 & 8.298 \\
$\mathrm{H} 7$ & $\mathrm{X} 7 \rightarrow \mathrm{Y}$ & 0.128 & 0.029 & 4.472 \\
$\mathrm{H} 8$ & $\mathrm{X} 8 \rightarrow \mathrm{Y}$ & 0.219 & 0.028 & 7.770 \\
\hline
\end{tabular}

Selanjutnya dalam mengevaluasi model struktural dengan PLS perlu dilihat nilai $R$-square untuk variabel laten endogen. Santosa (2018) menjelaskan bahwa besaran nilai $R$-square menunjukkan kekuatan prediktif dari model jalur, yang mana nilainya berkisar antara 0 sampai 1 , nilai $R$-square yang semakin mendekati angka 1 menandakan akurasi prediksi yang semakin besar. Pada penelitian ini terdapat satu variabel laten endogen yaitu Kecemasan Perpustakaan (Y), dengan nilai $R$-square sebesar 1,000 yang berarti variabilitas kecemasan perpustakaan dapat dijelaskan oleh delapan variabel laten eksogen sebesar $100 \%$.

\section{Pengujian Hipotesis}

Setelah dilakukan evaluasi terhadap model pengukuran dan model struktural, maka langkah

To cite this document:

Noprianto, E. (2019). Factors Affecting Library Anxiety of Graduate School Students in Gadjah Mada University. Record and Library Journal. 5 (2), 207-217

Open access under Creative Commons Attribution-Non Commercial-Share A like 4.0 International Licence 
terakhir adalah melakukan uji hipotesis. Berdasarkan jenis hipotesis yang telah diajukan, maka penelitian ini menerapkan uji hipotesis dua ekor (two tailed). Nilai $\boldsymbol{t}_{\text {tabel }}$ ditentukan dengan mengacu kepada:

a. Derajat kebebasan $(d f)=n-1$, dengan $n$ adalah jumlah responden (Santosa, 2018), maka: $d f=57-1=56$

b. Taraf kesalahan 0,05

Berdasarkan hasil penghitungan di atas, maka diperoleh nilai $\boldsymbol{t}_{\text {tabel }}=2,003$. Dengan demikian, hipotesis diterima jika nilai $\boldsymbol{t}_{\text {statistik }}>2,003$ dan hipotesis ditolak apabila $\boldsymbol{t}_{\text {statistik }}<2,003$. Mengacu kepada nilai $\boldsymbol{t}_{\text {statistik }}$ pada tabel 5 dan hasil perhitungan nilai $\boldsymbol{t}_{\text {tabel }}$, maka dapat diambil kesimpulan terhadap hipotesis sebagai berikut:

Hambatan pelayanan oleh pustakawan berpengaruh terhadap kecemasan perpustakaan. Hasil bootstrapping pada smartPLS menunjukkan bahwa hambatan pelayanan oleh pustakawan memperoleh nilai $\boldsymbol{t}_{\text {statistik }}$ sebesar 3,192 $(>2,003)$. Artinya terdapat pengaruh dan signifikansi antara variabel hambatan pelayanan oleh pustakawan terhadap variabel kecemasan perpustakaan. Dengan demikian hipotesis pertama dalam penelitian ini diterima.

Hambatan afektif berpengaruh terhadap kecemasan perpustakaan. Hasil bootstrapping pada smartPLS menunjukkan bahwa hambatan afektif memperoleh nilai $\boldsymbol{t}_{\text {statistik }}$ sebesar 7,992 (>2,003). Artinya terdapat pengaruh dan signifikansi antara variabel hambatan afektif terhadap variabel kecemasan perpustakaan. Dengan demikian hipotesis kedua dalam penelitian ini diterima.

Hambatan kenyamanan perpustakaan berpengaruh terhadap kecemasan perpustakaan. Hasil bootstrapping pada smartPLS menunjukkan bahwa hambatan kenyamanan perpustakaan memperoleh nilai $\boldsymbol{t}_{\text {statistik }}$ sebesar 5,131 (>2,003). Artinya terdapat pengaruh dan signifikansi antara variabel hambatan kenyamanan perpustakaan terhadap variabel kecemasan perpustakaan. Dengan demikian hipotesis ketiga dalam penelitian ini diterima.

Pengetahuan tentang perpustakaan berpengaruh terhadap kecemasan perpustakaan. Hasil bootstrapping pada smartPLS menunjukkan bahwa pengetahuan tentang perpustakaan memperoleh nilai $\boldsymbol{t}_{\text {statistik }}$ sebesar 2,471 (>2,003). Artinya terdapat pengaruh dan signifikansi antara variabel pengetahuan tentang perpustakaan terhadap variabel kecemasan perpustakaan. Dengan demikian hipotesis keempat dalam penelitian ini diterima.

Hambatan mekanis/teknologi berpengaruh terhadap kecemasan perpustakaan. Hasil bootstrapping pada smartPLS menunjukkan bahwa hambatan mekanis/teknologi memperoleh nilai $\boldsymbol{t}_{\text {statistik }}$ sebesar 8,238 (>2,003). Artinya terdapat pengaruh dan signifikansi antara variabel hambatan mekanis/teknologi terhadap variabel kecemasan perpustakaan. Dengan demikian hipotesis kelima dalam penelitian ini diterima.

Hambatan temu kembali berpengaruh terhad ap kecemasan perpustakaan. Hasil bootstrapping pada smartPLS menunjukkan bahwa hambatan temu kembali memperoleh nilai $\boldsymbol{t}_{\text {statistik }}$ sebesar 8,298 $(>2,003)$. Artinya terd apat pengaruh dan signifikansi antara variabel hambatan temu kembali terhadap variabel kecemasan perpustakaan. Dengan demikian hipotesis keenam dalam penelitian ini diterima.

Hambatan regulasi berpengaruh terhad ap kecemasan perpustakaan. Hasil bootstrapping pada smartPLS menunjukkan bahwa hambatan regulasi memperoleh nilai $\boldsymbol{t}_{\text {statistik }}$ sebesar 4,472 $(>2,003)$. Artinya terdapat pengaruh dan signifikansi antara variabel hambatan regulasi terhadap variabel kecemasan perpustakaan. Dengan demikian hipotesis ketujuh dalam penelitian ini diterima.

Hambatan sumber informasi berpengaruh terhadap kecemasan perpustakaan. Hasil bootstrapping pada smartPLS menunjukkan bahwa hambatan sumber informasi memperoleh nilai $\boldsymbol{t}_{\text {statistik }}$ sebesar 7,770 (>2,003). Artinya terdapat pengaruh dan signifikansi antara variabel hambatan sumber informasi terhadap variabel kecemasan perpustakaan. Dengan demikian hipotesis kedelapan dalam penelitian ini diterima.

\section{Faktor-Faktor yang Mempengaruhi Kecemasan Perpustakaan}

Penelitian Kurnia (2017) menemukan 5 faktor yang mempengaruhi kecemasan perpustakaan,

To cite this document:

Noprianto, E. (2019). Factors Affecting Library Anxiety of Graduate School Students in Gadjah Mada University. Record and

Library Journal. 5 (2), 207-217

Open access under Creative Commons Attribution-Non Commercial-Share A like 4.0 International Licence 
yaitu hambatan dengan pustakawan, hambatan afektif, hambatan kenyamanan perpustakaan, pengetahuan tentang perpustakaan, dan hambatan mekanis. Pada penelitian ini ditemukan ada 8 faktor yang mempengaruhi kecemasan perpustakaan pada mahasiswa Sekolah Pascasarjana UGM, yaitu hambatan pelayanan oleh pustakawan, hambatan afektif, hambatan kenyamanan perpustakaan, pengetahuan tentang perpustakaan, hambatan mekanis/teknologi, hambatan temu kembali, hambatan regulasi, dan hambatan sumber informasi. Dengan demikian, ada 3 faktor yang berpengaruh terhadap kecemasan perpustakaan pada mahasiswa Sekolah Pascasarjana UGM, yang belum ditemukan pada penelitian sebelumnya, yaitu hambatan temu kembali informasi, hambatan sumber informasi, dan hambatan regulasi.

\section{Simpulan}

Berdasarkan temuan dalam penelitian ini, didapatkan gambaran tentang kecemasan perpustakaan pada mahasiswa Sekolah Pascasarjana UGM, sehingga dapat diambil kesimpulan sebagai berikut:

Hasil penelitian ini membuktikan ada kecemasan perpustakaan pada mahasiswa Sekolah Pascasarjana UGM. Sebanyak 60 mahasiswa yang menjadi responden penelitian, kecemasan perpustakaan dialami oleh $95 \%$ atau sebanyak 57 mahasiswa. Kecemasan perpustakaan pada mahasiswa Sekolah Pascasarjana UGM dipengaruhi oleh 8 faktor dimensi, yaitu hambatan temu kembali; hambatan mekanis/teknologi; hambatan afektif; hambatan sumber informasi; hambatan kenyamanan perpustakaan, hambatan regulasi; hambatan pelayanan oleh pustakawan; dan pengetahuan tentang perpustakaan. Hambatan temu kembali merupakan faktor yang memiliki pengaruh paling tinggi, dan pengetahuan tentang perpustakaan merupakan faktor yang memiliki pengaruh paling rendah. Selain itu, ada beberapa faktor yang berpengaruh terhadap kecemasan perpustakaan pada mahasiswa Sekolah Pascasarjana UGM, yang belum ditemukan pada penelitian sebelumnya, yaitu hambatan temu kembali, hambatan sumber informasi, dan hambatan regulasi.

Beberapa saran yang dapat diberikan kepada pihak Perpustakaan UGM untuk mengatasi kecemasan perpustakaan tersebut. Pertama, mengingat hasil penelitian ini, faktor yang memiliki pengaruh paling besar adalah hambatan temu kembali, maka pihak Perpustakaan UGM perlu menyelenggarakan program literasi informasi secara berkala, untuk meningkatkan kemampuan temu kembali informasi mahasiswa. Kedua, pihak Perpustakaan UGM harus memperhatikan penempatan fasilitas atau perlengkapan perpustakaan untuk kemudahan penggunaannya. Saran untuk penelitian selanjutnya: Pertama, konstruk dalam penelitian ini memerlukan pengujian lebih lanjut di lingkungan perpustakaan yang berbeda, khususnya di lingkungan universitas yang ada di Indonesia. Dengan demikian, sangat disarankan para akademisi maupun praktisi bidang Ilmu Perpustakaan dan Informasi untuk melakukan pengujian validitas konstruk di tempat yang lain. Kedua, hasil penelitian ini membuktikan hambatan temu kembali merupakan faktor yang memiliki pengaruh paling tinggi terhadap kecemasan perpustakaan, sehingga disarankan ada penelitian tentang kemampuan temu kembali informasi pada mahasiswa Sekolah Pascasarjana UGM, untuk mendapatkan gambaran terperinci tentang kemampuan temu kembali mahasiswa.

\section{Referensi}

Ahmed, S. M. Z., \& Aziz, T. B. (2017). Use of Bostick's Library Anxiety Scale (LAS) in a developing country perspective. Library Review, 66(4/5), 282-296. doi: 10.1108/LR-06-2016-0052

Asra, A., Irawan, P. B., \& Purwoto, A. (2015). Metode Penelitian Survei. Bogor: In Media.

Bostick, S. L. (1992). The development and validation of the library anxiety scale. (Disertasi). Michigan: Wayne State University.

Erfanmanesh, M. (2011). Use of multidimensional library anxiety scale on Education and Psychology Students in Iran. Library Philosophy and Practice (e-Jurnal), 1-10. Retrieved from http://digitalcommons.unl.edu/libphilprac/563/

Ghozali, I. (2014). Structural Equation Model Metode Alternatif dengan Partial Least Squares (PLS):

To cite this document:

Noprianto, E. (2019). Factors Affecting Library Anxiety of Graduate School Students in Gadjah Mada University. Record and

Library Journal. 5 (2), 207-217

Open access under Creative Commons Attribution-Non Commercial-Share A like 4.0 International Licence

(CC-BY-SA) 
Dilengkapi Software Smartpls 3.0. Xlstat 2014 dan WarpPLS 4.0 (4th ed.). Semarang: Badan Penerbit UNDIP.

Indrawan, R., \& Yuniawati, P. (2016). Metodologi Penelitian: Kuantitatif, Kualitatif, dan Campuran untuk Manajemen, Pembangunan, dan Pendidikan (2nd ed.). Bandung: PT. Refika Aditama.

Jan, S. U., Anwar, M. A., \& Warraich, N. F. (2016). Library anxiety, library use and academic performance of undergraduate students in Pakistan. Library Review, 65(8/9), 564-577. doi: 10.1108/LR-03-2016-0024

Jiao, Q. G., \& Onwuegbuzie, A. J. (1997). Antecend ents of library anxiety. Library Quarterly, 67(4), 372-389.

Jiao, Q. G., \& Onwuegbuzie, A. J. (1999). Is library anxiety important? Library Review, 48(6), 278282. doi: $10.1108 / 00242539910283732$

Kurnia, B. E. (2017). Kecemasan di Perpustakaan (Library Anxiety) Mahasiswa Sekolah Pascasarjana Universitas Gadjah Mada. (Tesis). Yogyakarta: Universitas Gadjah Mada.

McPherson, M. A. (2015). Library anxiety among university students: A survey. IFLA Journal, 41(4), 317-325. doi: 10.1177/0340035215603993

Mellon, C. A. (1986). Library anxiety: A grounded theory and its development. College \& Research Libraries, 76(3), 276-282. doi: 10.5860/crl.76.3.276

Santosa, P. I. (2018). Metode Penelitian Kuantitatif: Pengembangan Hipotesis dan Pengujiannya Menggunakan SmartPLS (1st ed.). Yogyakarta: Andi.

Siregar, S. (2014). Statistika Deskriptif untuk Penelitian: Dilengkapi Perhitungan Manual dan Aplikasi SPSS Versi 17. Jakarta: Rajawali Pers.

Song, Z., Zhang, S., \& Clarke, C. P. (2014). Library anxiety among chinese students: Modification and application of las in the context of Chinese academic libraries. Journal of Academic Librarianship, 40(1), 55-61. doi: 10.1016/j.acalib.2013.10.014

Swigon, M. (2011). Library anxiety among Polish students: Development and validation of the Polish Library Anxiety Scale. Library and Information Science Research, 33(2), 144-150. doi: 10.1016/j.lisr.2010.09.003

To cite this document:

Noprianto, E. (2019). Factors Affecting Library Anxiety of Graduate School Students in Gadjah Mada University. Record and Library Journal. 5 (2), 207-217

Open access under Creative Commons Attribution-Non Commercial-Share A like 4.0 International Licence 